\title{
$\mathrm{PH} 102_{\text {setate }}$
}

a debate Comunicación y redes sociales en instituciones culturales

| coordina Candela González Sánchez

\section{La comunicación digital en las artes escénicas españolas}

Adriana Lerena | comunicación y promoción cultural, Lemonpress

URL de la contribución <www.iaph.es/revistaph/index.php/revistaph/article/view/4827>

¿Qué cultura está en las redes? ¿Cuáles son las estrategias de comunicación que lideran las instituciones culturales? ¿Cuáles son las prácticas comunicativas de las que podemos aprender y aquellas de las que deberíamos huir? ¿Las redes alargan la experiencia cultural? Estas son solo algunas de las cuestiones iniciales que se plantean para generar este debate, pero, a su vez, abren un sinfín de debates en paralelo e independientes, muy difíciles de responder en un breve artículo.

Este año ha sido bautizado por la Organización de las Naciones Unidas como el "año del salto tecnológico", y es que hablar de comunicación digital en el 2020 sin tener en cuenta los efectos de la COVID-19 a todos los niveles sería irreal. La pandemia ha supuesto un cambio en los paradigmas de comunicación y, sin duda, una revolución digital acelerada que en nuestro país quizá hubiera tardado años en producirse. El mundo de la cultura no ha querido quedarse atrás y ha debido adaptar sus entornos digitales ante la urgencia impuesta por la actualidad y una realidad muy obsoleta en la gran mayoría de los casos.

La transformación tecnológica y la innovación ayudan a mostrar la universalidad de la cultura y el arte, y hacen que sus instituciones sean más accesibles a todos los ciudadanos. Para ello es imprescindible el desarrollo de herramientas que permitan una democratización real de la información y del arte integrando también a la ciudadanía.

La realidad es que somos datos, el Estudio Anual de Redes Sociales 2020, desarrollado por IAB Spain, explica que 26 millones de personas utilizan redes sociales en nuestro país, y de ellos un $86 \%$ lo hacen a diario con la finalidad de entretenerse, interactuar con los demás y mantenerse informado, por lo que la captación de este público y crear una cultura digital debería ser una prioridad del sector cultural español.
Internet ofrece nuevas y múltiples oportunidades para recopilar datos y para poner en práctica una amplia gama de métodos cualitativos y cuantitativos con los que medir el impacto de las actividades, pero esto conlleva dedicar también muchos recursos al análisis de datos y audiencias. Lo que es innegable es que, hoy, los datos que se obtienen del ámbito digital representan una gran oportunidad para que las instituciones puedan adquirir un mayor entendimiento de su público y puedan ofrecer experiencias más satisfactorias.

A diferencia de los museos, que trabajan desde hace tiempo en poder ser visitados a distancia y en acercar el arte y la cultura más allá de sus salas, el sector de las artes escénicas en España va un poco atrasado en cuanto a revolución digital. No son habituales los estudios de públicos, ni una estrategia digital rigurosa y, además, no son muchos los organismos que han apostado en estos años por ampliar sus departamentos con profesionales que asuman las tareas de comunicación y marketing digital y que tengan los conocimientos necesarios para desempeñar esas tareas.

Sin embargo, el 2020 ha sido un punto de inflexión. El teatro, que es el reino de lo presencial y de lo vivo, como ceremonia milenaria que es, ha tenido que repensarse frente a la COVID-19.

¿Cómo sobrevivir a este "apagón cultural"? Durante los últimos meses, el teatro ha llegado virtualmente a las personas y sus hogares a través de propuestas y nuevos formatos mezcla, en muchas ocasiones, de una simbiosis de artes escénicas y audiovisuales.

El Centro Dramático Nacional (CDN) apostó claramente por el streaming, algunos espectáculos podían verse de manera gratuita en su web y en sus redes sociales incluso meses después de la primera ola de la pande- 
mia. La plataforma HBO anunció una serie que también combinaba géneros bajo el título de Escenario 0 . El célebre Festival de Otoño de Madrid optó por duplicar su formato haciéndolo presencial y virtual y en el Festival Grec de Barcelona hubo un espectáculo con tres cámaras integradas dentro del montaje.

Algunos creadores pusieron en marcha experiencias teatrales por WhatsApp, con imágenes y canciones que llegaban al móvil y en las que el espectador podía elegir incluso la voz del actor o actriz de su obra. Se hizo radioteatro musical a través de podcasts, emisiones de obras de archivo, piezas creadas por la video plataforma Zoom, audio teatro con audioguía en viajes por el Raval... y es que, una vez más, queda patente que el sector de las artes escénicas muestra su fortaleza como sector creativo y resiliente que siempre sale reforzado ante las grandes crisis.

Hay quienes creen que todos estos cambios permanecerán y otros, como Salvador Sunyer, director del festival Temporada Alta, ha manifestado que "Hacer streamings de obras teatrales está bien para un momento excepcional, pero eso no quedará". Lo que sabemos es que antes de la pandemia el sector necesitaba mejorar su presencia digital, los eventos del último año han dado el empujón que el sector necesitaba pero ahora el reto está en mantener las nuevas estrategias aprendidas y desarroIlarlas más allá de los tiempos de la COVID-19. El marketing cultural está aquí para quedarse y las redes sociales están ganando la batalla de la creación de audiencias.

Sin embargo, después de estas reflexiones y de estos meses extraños, me surge una última cuestión con la que me gustaría concluir: ¿realmente ha habido una transformación digital o esto solo ha sido una adaptación digital en un momento de necesidad?

\section{BIBLIOGRAFÍA}

- Barranco, J. (2020) El teatro se reinventa por la pandemia. La Vanguardia, 10 de agosto de 2020. Disponible en: https:// www.lavanguardia.com/cultura/20200810/482751302062/ teatro-virtual-digital-grec-temporada-alta-roger-bernatpandemia.html [Consulta: 20/12/2020]

- Fundación iS+D (2020) Análisis de la cultura virtual en las redes sociales como organización digital. 9 de noviembre de 2020. Disponible en: https://isdfundacion.org/2020/11/09/ analisis-de-la-cultura-virtual-en-las-redes-sociales-comoorganizacion-digital/ [Consulta: 20/12/2020]

- IAB Spain (2020) Estudio Anual de Redes Sociales 2020. 17 de junio de 2020. Disponible en: https://iabspain.es/estudio/ estudio-redes-sociales-2020/ [Consulta: 20/12/2020]

- Miranda, D. P. (2020) El teatro en tiempos de pandemia. Literal magazine, 15 de julio de 2020. Disponible en: https:// literalmagazine.com/el-teatro-en-tiempos-de-pandemia/ [Consulta: 20/12/2020]

- Pérez Lapuente, V. (2020) La tecnología al servicio del arte y la cultura. Minsait, 19 de Noviembre de 2020. Disponible en: https://www.minsait.com/es/actualidad/insights/la-tecnologiaal-servicio-del-arte-y-la-cultura [Consulta: 20/12/2020]

- Villaespesa, E. (2018) Evaluación de la estrategia digital en los museos: métodos y herramientas para web, redes sociales y móviles. Periférica Internacional. Revista para el análisis de la cultura y el territorio, (19), pp. 38-53. Disponible en: https://revistas.uca.es/index.php/periferica/article/view/4902 [Consulta: 20/12/2020]

- Wiener, G. (2020) Volver al teatro durante la pandemia.The New York Times, 20 de octubre de 2020. Disponible en: https:// www.nytimes.com/es/2020/10/20/espanol/opinion/teatrocovid.html [Consulta: 20/12/2020] 